Pujantara

\title{
PENGARUH PRESEDEN ARSITEKTUR DUNIA TERHADAP KARAKTERISTIK BENTUK FASADE BANGUNAN DI KOTA MAKASSAR
}

\author{
Ruly Pujantara \\ Jurusan Sipil dan Perencanaan Fakultas Teknik Universitas Negeri Makassar \\ rulypujantara@gmail.com
}

\begin{abstract}
Abstrak
Pada era modern sekarang ini, fasade dan bentuk bangunan yang berkembang dan di bangun di kota-kota besar Indonesia adalah kebanyakan fasade dan bentuk bangunan modern dan futuristik. Desainnya mempunyai karakteristik tertentu sesuai gaya Arsitektur Eropa, Amerika dan Jepang. Originalitas fasade bangunan dan bentuk bangunan modern di Indonesia juga mengalami adaptasi mengikuti preseden Arsitektur dunia. Preseden Arsitektur ini menjadi sedikit masalah ketika unsur keamanan, kenyamanan menjadi hilang dan menjadi gangguan dalam struktur perencanaan dan perancangan bangunan di Indonesia. Bagaimana adaptasi karakter fasade pada lingkungan, bentuk preseden arsitektur dan akibatnya kepada keseluruhan desain pasca huni , akan menjadi inti bahasan dalam tulisan ini di dasarkan pada tinjauan filosofi, ilmu pengetahuan, rekayasa teknik dan seni. Membaca dan mengidentifikasi karakteristik dari preseden yang menjadi tema dalam sebuah desain dilakukan dengan membandingkan langsung fasade, bentuk, pola geometri, skala, bidang vertikal dan horizontal yang mempengaruhi pola desain dari arsitek bersangkutan. Hasilnya adalah beberapa bangunan komersial di kota Makassar sangat dipengaruhi oleh preseden arsitektural dari luar, langgam kelokalan hilang, sedangkan bangunan pemerintahan walaupun sedikit dipengaruhi preseden arsitektur dari luar namun masih tetap memasukkan langgam arsitektur lokal dan kultur daerah setempat sebagai identitas kedaerahan.
\end{abstract}

Kata kunci: Preseden, arsitektur, karakter, fasad

\begin{abstract}
In this modern era, futuristic buildings form and facade, nowdays, can be seen at big towns in Indonesia. The design has certain characteristic in accordance to eropean, american and japanese architecture style. The originality of it's facades were changed, adopting the global architectural precedents, and sometimes its turn into problems when adopting process ignoring comfortness, safety, and structure. How is the facade characeristic, the form of precedent, and its impact are the essences of this paper. Discussion constructed based on review of philosophy, science, engineering and art. To read and identify the characteristics of precedent were done by comparing directly the facade, shape, geometry pattern, scale, vertical and horizontal plane that affect the pattern of design. From the result: for some commercial buildings in the Makassar city were strongly influenced by the architectural precedent from the outside, the style of its localities was disappearing. For the government buildings, although is slightly influenced by the architectural precedents from the outside, but its still keeping the local architectural style and culture of the local area as a regional identity.
\end{abstract}

Keywords: Precedent, architecture, character, facade

Langkau Betang, Vol.2, No.2, 2015. Hal. 116 


\section{Pendahuluan}

Penampakan fasade dan bentuk bangunan-bangunan modern dengan gaya internasional maupun gaya dekonstruksi, pada kota-kota besar di Indonesia terlihat dari banyaknya bangunan - bangunan tersebut yang menghiasi wajah kota dan bahkan di jadikan sebagai landmark. Wajah disain seperti ini tidak lepas dari masuknya pengaruh-pengaruh arsitektur dunia dari luar dengan dipelajarinya preseden arsitektur kepada para mahasiswa arsitektur dan calon arsitek sehingga kondisi ini memungkinkan terserapnya karakter-karakter fasade dan bentuk desain dari arsitek luar tersebut dan terlihat pada hasil desain para arsitek-arsitek di Indonesia. Keberadaan fenomena ini, sedikit banyak memberikan wajah kental preseden arsitektur luar tersebut, tanpa melihat bagaimana kesesuaian dan sustainability terhadap lingkungan lokal sekitar maupun local wisdom dan kultur daerah setempat khususnya di Indonesia, sehingga hal tersebut menjadi semacam shock culture dan trend oriented alih-alih sebagai target oriented.

\section{Metode Penelitian dan Observasi}

Metode penelitian yang digunakan adalah metode observasi dan survey, penelitian ini merupakan deskripsi kualitatif, yaitu membuat gambaran dan paparan serta menggali secara cermat dan mendalam tentang karakteristik asli fasade dan bentuk bangunan arsitektur dari arsitektur dunia yang dipresedenkan dan adaptasi karakteristik preseden arsitektur dunia tersebut pada bangunan modern yang ada di Indonesia, khususnya di kota Makassar. Metode pengumpulan data dilakukan antara lain melalui pengumpulan data primer melalui survey, observasi, dan data sekunder berbagai instansi yang terkait dan informasi berupa tulisan, koran, buku-buku dan studi literatur. Dalam teknik analisisnya digunakan analisis deskriptif, komparatif dan inferensial dengan data dari literature, foto kolase, analisis peta. Adapun beberapa data yang digunakan adalah sebagai berikut:

1. Data hasil plotting: lokasi sebaran bangunan preseden Arsitektur luar di Kota besar Makassar.

2. Data survey berupa foto bangunan yang di identifikasi memiliki kesamaan karakter dengan preseden tertentu.

3. Data sekunder dari pemerintah setempat, artikel media massa, dokumentasi dan literature yang terkait.

\section{Tinjauan Pustaka \\ Preseden Arsitektur}

Preseden arsitektur adalah sebuah penilaian atau alat analisis untuk melatih kecakapan desain arsitektur dan memberikan karakter tertentu pada desain arsitektural seorang arsitek. Metodologi penilaian karya arsitektural yang mempunyai karakteristik tertentu, yang secara mendalam meliputi 3 aspek yaitu (Siregar, 2011):

a) Aspek Konseptual

b) Aspek Progmatik

c) Aspek Formal

Penilaian terhadap arsitektur pada dasarnya sangat berhubungan dengan stimulasi visual dan etika visual (Antoniades, 1991). Secara otomatis shape dan fasade merupakan hal yang krusial selain tata ruang, tata tapak dan tata landscape dalam kriteria makro dan mikro, sebagai uraian global dalam perencanaan dan perancangan arsitektural. Dalam aspek konseptual, preseden arsitektur lebih terfokus kepada teori-teori bentuk, proses transformasi dan philosophy, sedangkan dalam aspek progmatik, preseden arsitektur terfokus kepada tata ruang, konfigurasi, morfologi, geometri dan layout denah atau bangunannya, sedangkan aspek formal, preseden arsitektur terfokus kepada hal formal seperti tapak, lingkungan, peraturan dan sustainability. Aspek konseptual adalah bahasan utama karena berdasar 
konseptual tersebut semua kriteria perencanaan dan perancangan di tetapkan berdasarkan landasan kriteria tersebut. Oleh karena itu teori-teori bentuk, transformasi dan filosofi lebih kental dalam stimulasi serta etika visual.

Berikut beberapa teori-teori dalam arsitektur yang berasal dari arsitek luar dengan gagasangagasan dalam transformasi bentuk yang muncul sekitar tahun 1998 setelah post-modern. Teori yg barkaitan dgn aspek normatif \& aspek unnormatif dlm proses perencanaan dan perancangan. Yaitu pengembangan teori - teori yang prosesnya mengambil seluruh bagian yang diberikan dan menentukan jalan baru untuk menggabungkan bagian-bagian, mengembangkan kemungkinan-kemungkinan baru, penyusunan baru dibawah aspek unormatif dan normatif.

\section{Dekonstruksi-Dekomposisi}

Merupakan salah satu pendobrak teori form follow fuction, dekonstruksi ini melawan kaidah konstruksi yang ada, gubahan massa yang tidak teratur, terdistorsi, abstrak bahkan anti gravitasi, diangkat dalam paham ini (I.Makainas, 2011). Kaidah-kaidah tradisional dalam arsitektur klasik maupun modern yang selama bertahun-tahun dan bahkan berabad - abad diyakini dan dijadikan sebagai dasar perancangan ditentang secara radikal dan konseptual melalui eksplorasi dan olah kreatifitas dalam desain. teknologi struktur serta teknologi bahan yang mutakhir adalah suatu keharusan untuk teori ini. Penggagas dan penganut teori ini adalah :

a. Thom Mayne ( USA )

b. Zaha M. Hadid ( UK )

c. Frank O. Gehry ( USA )

d. Enric Miralles ( Spain )

e. Eric Owen Moss ( USA )

Karakter inti dari Dekonstruksi ini adalah pola geometri bebas dan tak terarah, pos strukturalis yang kuat dengan bentang lebar tanpa penyanggah struktural, garis-garis vertikal dan horizontal yang tegas menyilang pola bidang geometri, ataupun garis-garis lengkung yang mengalir bebas, Serta bidangbidang lempengan geometri yang mengarah bebas, terpuntir atau terlipat (Purnomo.S, 1997). Beberapa karya Dekonstruksi dari para penganutnya:

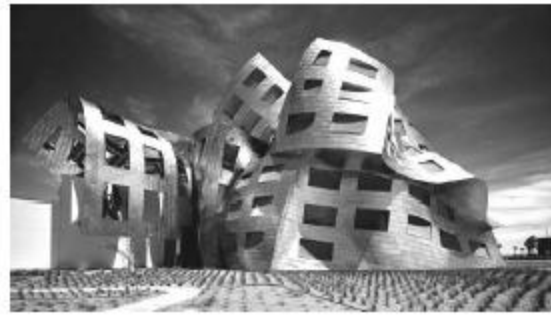

Gambar 1

Health Center, Cleveland - Frank Gehry

Irregural shape - brutality Sumber : Frank Gehry.com

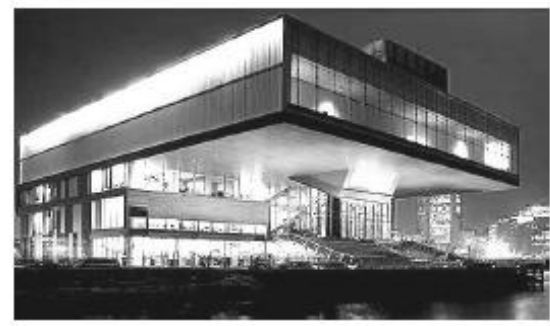

Gambar 2

Blur Building,Boston - Tom Mayne\&Diller Cantilever Wide span Structure - Deconstructivisı Sumber : Tom Mayne.com

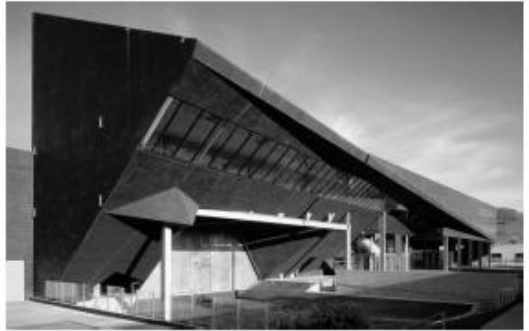

Gambar 3 Stealth Building,California-Eric O.Moss Folded structure - Deconstructivism Sumber : Eric Owen Moss.com 




Gambar 4

Hypo Bank,Austria - Tom Mayne Folded and Cantilever Structure Sumber : Morphosis.com

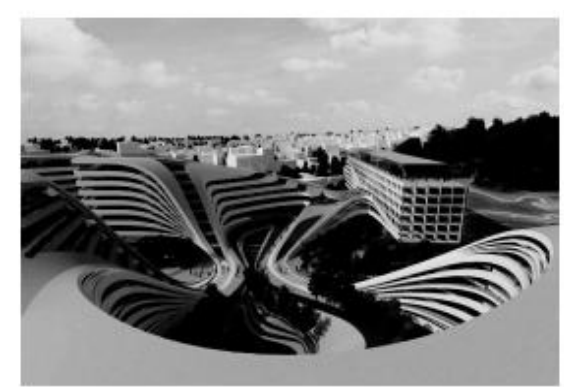

Gambar 5

Beko master,Belgrade - Zaha Hadid Organic Curves - Deconstructivism Sumber : Zaha Hadid Architec.com

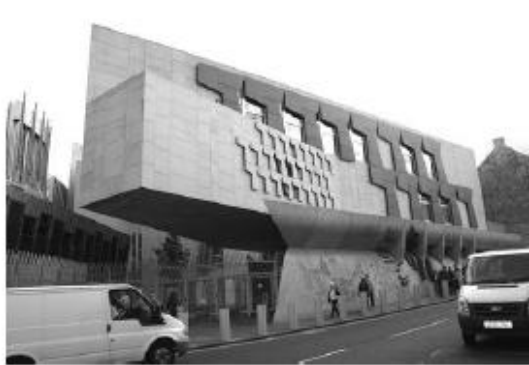

Gambar 6

The Parliament,Scotland - Enric Miralles Cantilever Structure - Deconstructivism Sumber : Enric Miralles.com

\section{Superimposition (unnormatif)}

Teori yang memuat konsep tumpang tindih 2 atau lebih fungsi, program atau bentuk geometri dengan keteraturan tertentu yang berbeda menjadi suatu yang baru (Atmoko, 2003). Metode Ini berupa Penggabungan (integration) dan Bantalan podium (mounting) (Jeraman, 2010). Penggagas dan penganut teori Superimposition ini adalah :

a. Bernard Schumi ( Germany )

b. Richard Meyer ( USA )

c. Frank Lloyd Wright ( USA )

d. Hans Hollen ( Austria )

Karakter inti dari superimposition adalah pola geometri spatial (ruang), garis atau bidang lempengan geometri yang bertumpuk dan teratur walaupun ukuran, arah, orientasi dan bentuk geometrinya berbeda (Jeraman, 2010). Beberapa karya Superimposition dari para penganutnya ;

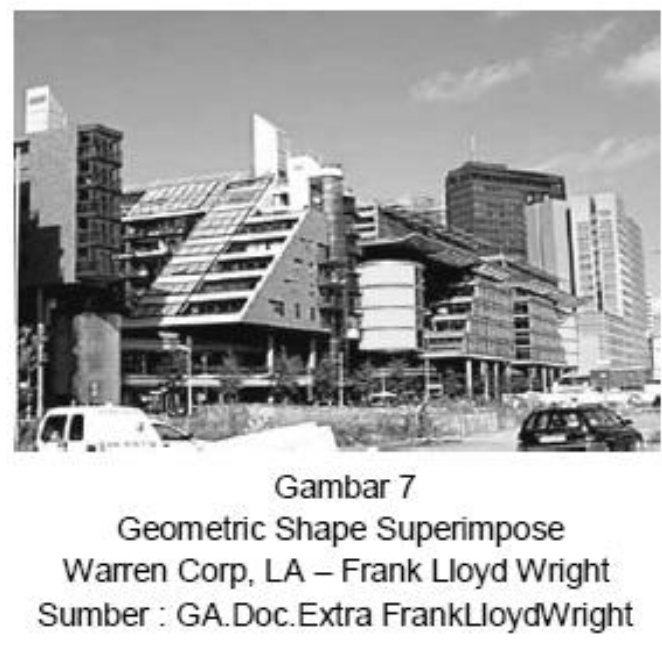

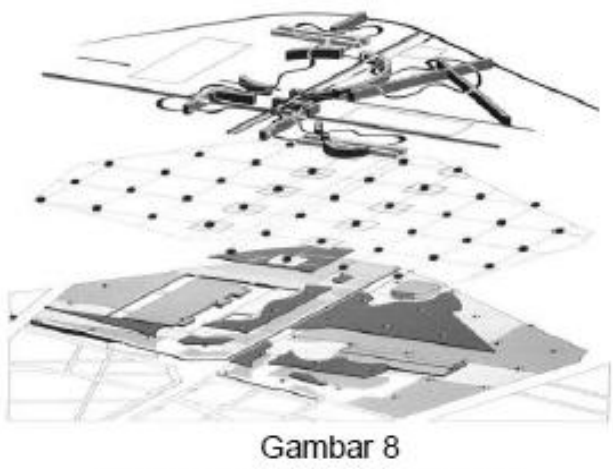

Line and Spatial Superimpose

Parc de LaVillete,France - Bernhard Schumi Sumber : GA.Doc. Extra Bernhard Schumi.

Hal 119. Langkau Betang, Vol.2, No.2, 2015 

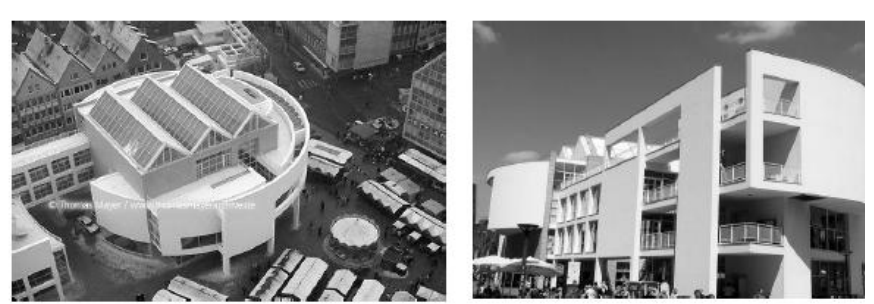

Gambar 9 dan Gambar 10

Geometric Shape Superimpose Stadhaus Ulm, German - Richard Meyer

Sumber : ThomasMeyerArchive.de dan GA.Doc. Extra Richard Meyer
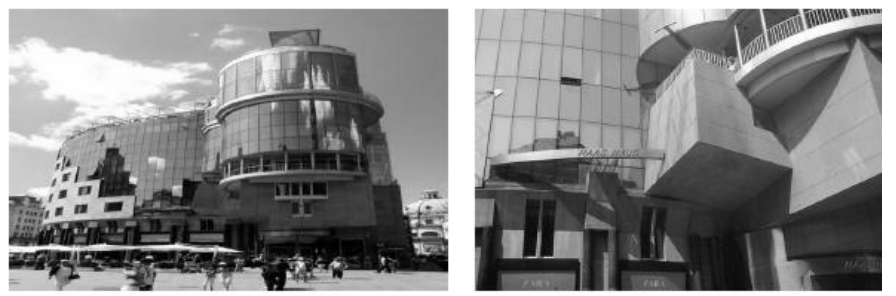

Gambar 11 dan Gambar 12 Geometric Shape Superimpose Haas haus Vienna,Austria - Hans hollien Sumber : panoramio.com

\section{Hybrid (unnormatif)}

Adalah teori yang menggabungkan serta mempersenyawakan (adaptif blending) 2 atau lebih teori, fungsi dan bentuk yang berbeda menjadi suatu fungsi serta bentuk baru. Metode ini berupa penembusan (penentration), pencakupan (embracing), Penjepitan (clamping), Penjalinan (Interlacing) (Jeraman, 2010). Penggagas dan penganut teori ini adalah :

a. Coop Himmel Blau ( Austria)

b. Norman Foster ( UK )

c. Peter Eisenman ( USA )

d. Mecanoo ( Dutch)

Karakter inti dari hybrid adalah pola geometri, garis atau bidang lempengan geometri yang berpotongan dan tidak teratur dengan ukuran, arah, orientasi dan bentuk geometrinya berbeda. Garis vertical dan horizontal yang dinamis (Atmoko, 2003). Beberapa karya hybrid dari para penganutnya :
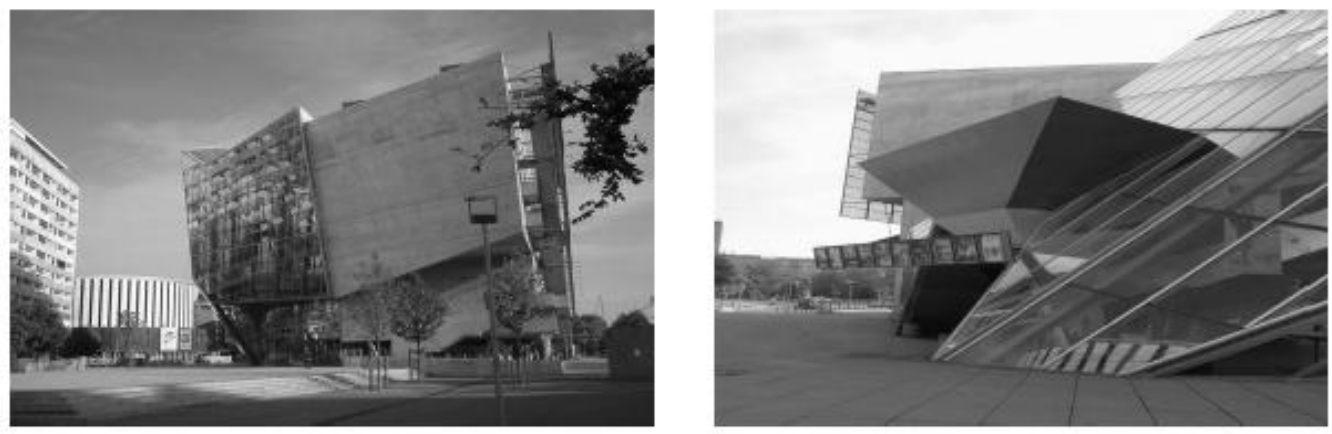

Gambar 13 dan Gambar 14

Geometric shape hybrid, irregural shape

UFA Cinema Center,Dresden - Coop Himmelblau

Sumber : GA.Doc. Extra International 99 


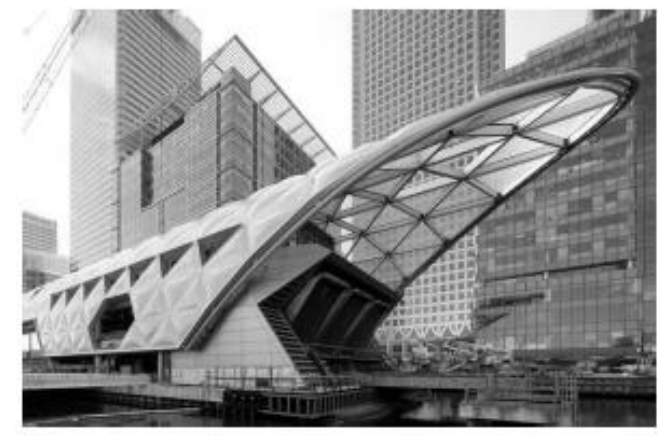

Gambar 15

Geometric Shape Hybrid Organic curves with space frames Canary warf,UK - Norman Foster Sumber : Arcspace.com

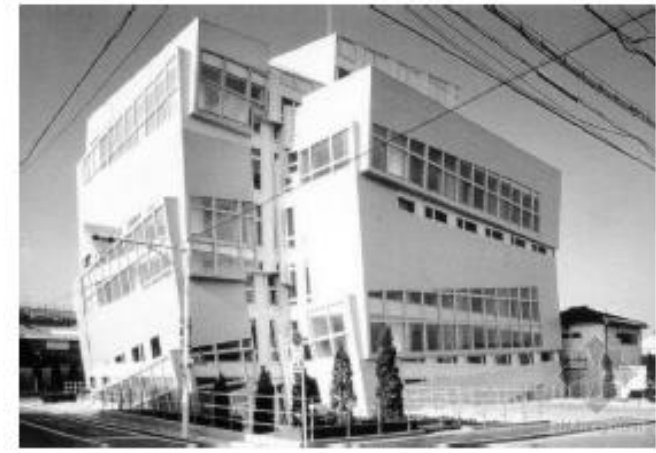

Gambar 16

Geometric shape hybrid folded space Nunotani Building,Japan - Peter Eisenman Sumber: Arcspace.com

\section{Transposisi (unnormatif)}

Adalah tata cara penyusunan bentuk ataupun program perancangan yang sudah diterapkan dengan aturan tertentu yg mengacu pada standart umum: translasi, rotasi, skala, pencerminan, array objek bahkan dengan pendekatan program spatial dengan cross-programing untuk program yang sama sekali berbeda seperti museum dalam bangunan parkir, transprograming untuk program yang sifat dan spatialnya berbeda seperti : planetarium dgn roller coaster atau perpustakaan dengan arena balap mobil, dan disprograming untuk program yang sifatnya saling mengkontaminasi dengan program lainnya misalnya supermarket dikombinasikan dengan perkantoran, dan lain-lain (I.Makainas, 2011). Penganut teori ini adalah :

a. Tadao Ando ( Japan )

b. Hiroshi Hara ( Japan )

c. Arata Isozaki ( Japan )

d. Ricardo Legorreta ( Mexico )

e. Dominique Perrault ( France )

Karakteristik inti konsep ini adalah perulangan bentuk dengan pola geometri planar, penggunaan material waterpool pada site untuk pencerminan, array objek dengan rotasi baik secara radial maupun linear (Atmoko, 2003). Beberapa karya Transposisi dari para penganutnya :

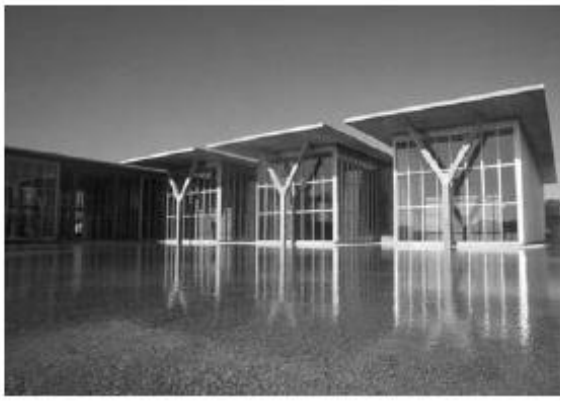

Gambar 17

Repetisi Bentuk

Museum Art, Texas - Norman Foster

Sumber : Arcspace.com

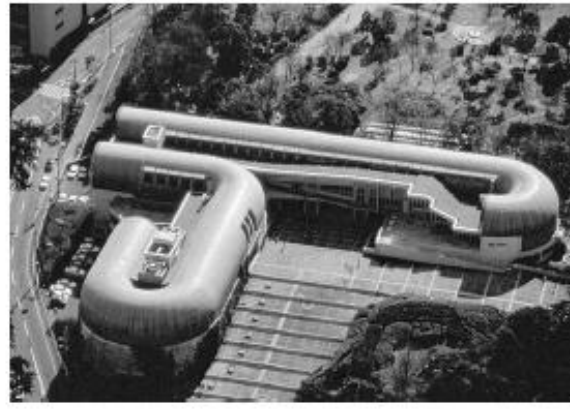

Gambar 18 Rotasi Radial

City Library,Japan - Arata Isozaki Sumber : Arcspace.com

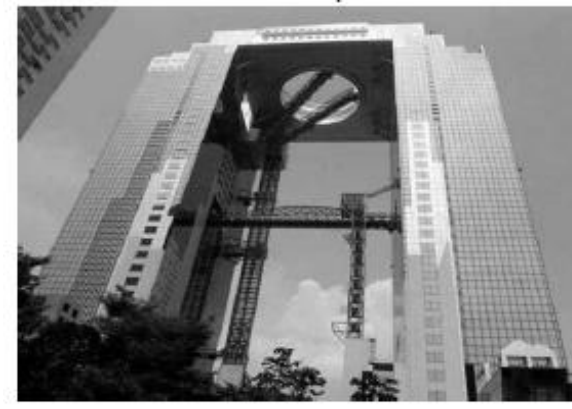

Gambar 19

Umeda Building, Japan - Hiroshi hara Sumber : raidingfoundation.org

Hal 121. Langkau Betang, Vol.2, No.2, 2015 


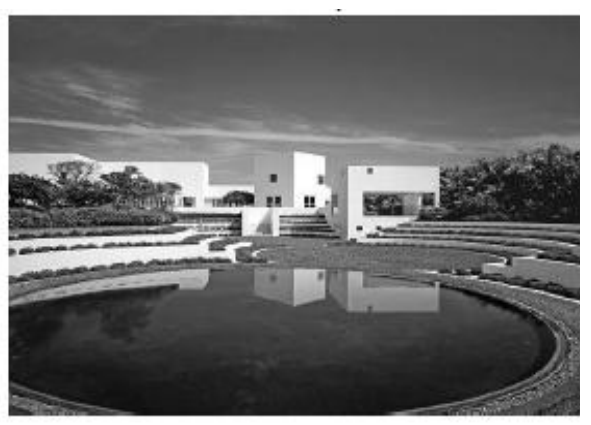

Gambar 20

Nun, Spain - Ricardo Legorreta

Sumber : Architecturedigest.com

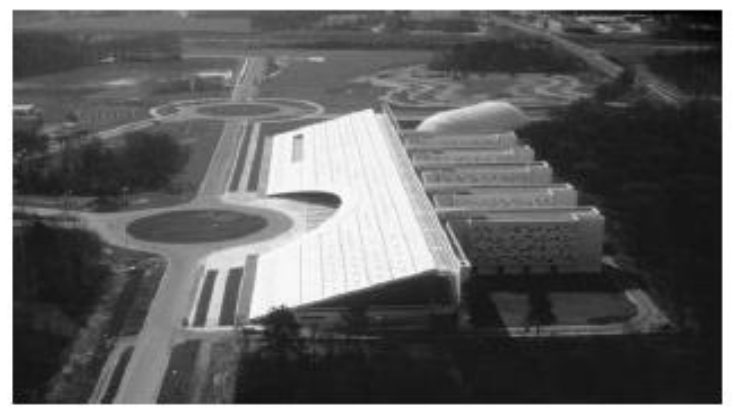

Gambar 21

Media Library, France - Dominique Perrault Sumber : panoramio.com

\section{Morphosis (unnormatif)}

Perubahan bentuk dan fungsi dikarenakan oleh seleksi alam atau kriteria perubahan lingkungan yang cepat dan tersistem (dengan teknologi) secara tepat membentuk sesuatu yang baru, pandangan yang baru, fungsi serta potensi baru yang lebih baik dan sempurna (Atmoko, 2003). Teknologi advance, green architecture, sustainable architecture dan environment issue adalah syarat dari metamorphosis atau biasa disebut sebagai Technomoprism (I.Makainas, 2011). Penganut dan penggagas Teori ini adalah :

a. Thom Mayne ( USA )

b. Steven Holl ( Sweden )

c. Toyo Ito ( Japan )

Karakteristik Morphosis yang berasal dari Tom Mayne ini konsep bebas dan issu metamorphosis yang kuat, yaitu tilted walls and floors, pola perubahan baru geometri rupa dengan bentuk platonic solid serta organic form seperti kristal atau permata secara teknologi menyeluruh dengan flying beams tanpa alasan yang jelas, lebih menonjolkan pada segi estetisnya. Komposisi massa yang asimetris, bentuk tidak beraturan, dinding miring, penggunaan material beton serta kaca menjadikan ciri tersendiri dari Morphosis. Berikut karya morphosis dan para penganutnya :



Gambar 22

University of cincinnati,US - Tom Mayne

Sumber : panoramio.com

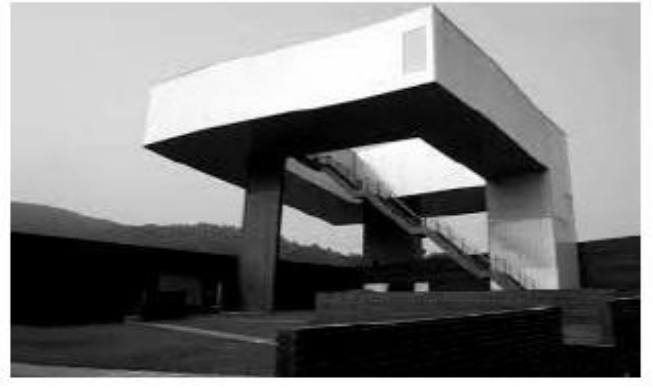

Gambar 23

Nanjing Art Museum, Cina - Steven Holl

Sumber : Architecturedigest.com



Gambar 24 Vira Hotel, Japan - Toyo Ito Sumber : panoramio.com

\section{Arsitektur Kamasutra (unnormatif)}

Teori pengungkapan dari aspek kehidupan yang dinamis. Secara narasi, simbolis, filosofis serta empiris. Penyusunan doktrin atau filsafat mengenai seks bahwa tubuh dalam setiap setting gambar yang dinarasikan memberikan semacam gagasan bahwa setiap adegan menyimpan konfigurasi arsitektural 
tubuh dan ruang sebagian lagi teori ini berdasar dari teori hybrid. Gagasan ini pertama kali diketengahkan oleh Agustinus Sutanto: "Disini tidak ada tempat untuk memunculkan canda yang bersifat cabul ataupun tertawa sinis. Memang disana ada kelucuan tetapi merupakan senyuman musim semi dan bukan tertawaan keras kosong dari orang2 bodoh".



\section{Fasade}

Menurut Krier (1988), facade berasal dari akar kata Latin facies, yang sama pula pengertiannya dengan face dan appearance. Oleh karena itu, jika menyebutkan wajah dari suatu bangunan, digantikan dengan istilah atau kata facade, terutama yang dimaksudkan adalah bagian depan dari suatu bangunan yang menghadap ke jalan. Fasade bangunan tampaknya masih merupakan elemen arsitektural yang tidak hanya memenuhi keperluan-keperluan umum yang dianjurkan oleh organisasi ruang-ruang yang berada dibaliknya.Fasade juga mencerminkan situasi kultur pada saat bangunan tersebut didirikan; mengungkapkan pula kriteria-krireria penataan, serta mempertimbangkan kemungkinan-kemungkinan dan keahlian pemberian ornamen dan dekorasi. Fasade Juga memberitahukan tentang penghunipenghuni suatu bangunan, yang mengekspresikan suatu identitas kolektif sebagai sebuah komunitas, yang pada akhirnya direpresentasikan kepada publik.

\section{Hubungan Fasade dengan Karakteristik lingkungan dan iklim}

Arsitektur sebagai bangunan merupakan salah satu sudut pandang tentang arsitektur, menganut pemahaman bahwa bangunan (building) seharusnya memenuhi 3 lingkup pemahaman (Heryanto, 2003), sebagai berikut ;

a) Bangunan yang menyesuaikan kondisi lingkungannya (Building Environmental) artinya bahwa seluruh unsur dan elemen bangunan beradaptasi untuk tujuan pelestarian lingkungan,

b) Bangunan yang memenuhi persyaratan teknis (Building Requirement) artinya bahwa bangunan seharusnya memenuhi persyaratan teknis bangunan,

c) Bangunan yang memenuhi jalinan kerangka dari faktor-faktor penentunya (Building Determinant) artinya bahwa bangunan dan pembangunannya seharusnya mengikuti seluruh faktor-faktor yang harus ada

Hal 123. Langkau Betang, Vol.2, No.2, 2015 
Pada prinsipnnya komposisi fasade dilakukan dengan menciptakan kesatuan yang harmonis dengan menggunakan komposisi yang proporsiornal, unsur vertikal dan horizonta1 yang terstruktur, material, warna, dan elemen-elemen dekoratif. Hal ini yang tidak kalah penting untuk mendapatkan perhatian yang lebih adalah proporsi, bukaan-bukaan, tinggi bangunan, prinsip perulangan, keseimbangan komposisi yang baik, serta tema yang tercakup ke dalam variasi (Krier, 1988:72). Kesatuan yang harmonis antara lain dicapai dengan prinsip-prinsip komposisi, yaitu adanya dominasi, perulangan, dan kesinambungan. Pemakaian material, warna dan elemen-elemen dekoratif tertentu dengan berpijak pada karakteristik visual yang dimiliki bersama - akan memberikan keterkaitan visual yang mewujudkan kesatuan desain. Tinggi keseluruhan bangunan berkaitan dengan komposisi garis langit (skyline) antar bangunan yang dimunculkan. Sedangkan unsur vertikal dan horizontal yang terstruktur berkenaan dengan konfigurasi unsur-unsur bidang fasade, seperti jendela, pintu masuk dan sunblinds. Ulasan tersebut di atas dirangkum untuk menghasilkan kriteria penataan fasade yang mencakup.:

a. Prinsip-prinsip komposisi

b. Penyelesaian akhir (bahan/material, warna, tekstur)

c. Proporsi arsitektural fasade (perbandingan bukaan-masif, vertikalitas-horizontalitas, keterkaitan visual)

d. Pemakaian elemen dekoratif.

Elemen-elemen fasade yang lain adalah bidang dinding, kolom, dan ballustrade. Elemen-elemen fasade inilah yang akan dikaji terhadap kriteria penataan fasade yang akan dirumuskan nanti. Fasade bangunan merupakan bagian dari elemen fisik tata bangunan yang berada pada konteks perancangan kota. Penataan fasade bangunan haruslah mempertimbangkan integrasinya terhadap komponen perancangan kota yang mempengaruhi fasade. Beberapa komponen atau elemen fasade yang dikemukakan pada konsep perancangan, kurang relevan dengan kondisi lokal pada kawasan studi, oleh sebab itu perlu dilakukan penyesuaian/pengurangan; terhadap beberapa elemen tersebut di atas. Sehingga komponen atau elemen yang mempengaruhi perancangan kualitas estetis suatu koridor kota terutama pada kawasa studi, diantaranya adalah Corak Fasade, Atap Bangunan, Dinding Bangunan dan Pemunduran Bangunan.

\section{Corak Fasade / Arsitektur}

Penilaian suatu fasade pada koridor jalan adalah, unsur corak fasade yang memegang peranan penting dalam menentukan orientasi kawasan dan lingkungan. Selain itu, ciri khas sebuah kota adalah adanya kawasan-kawasan yang dapat dilihat atau dipahami tampilan arsitekturalya sebagai serial vision (Cullen, 1975: 11).

\section{Atap Bangunan}

Atap bangunan merupakan elemen fasade yang berfungsi sebagai 'kepala' bangunan. Pembentukan fasade secara umum, selalu mendahulukan kondisi skyline sebagai orientasi ketinggian suatu bangunan, yang nantinya akan membentuk kesan awal secara keseluruhan. Pada map bangunan terdapat tiga faktor yang menentukan perancangan suatu fasade, yaitu :

Bentuk Atap

Hal pertama yang terperhatikan dalam keserupaan adalah bentuk. Dan apabila keserupaan bangunan terimplementasikan dalam konteks dinding bangunan, maka perhatian akan jatuh pada bentuk atap. Bentuk atap menduduki prioritas bobot tertinggi dalam pemilihan elemen atap bangunan, karena dalam pencahayaan rendah sekalipun, bentuk masih tetap akan terlihat dalam bentuk siluet. Oleh sebab itu, peranan bentuk atap dalam pembentukan kesan fasade yang ditampilkan' amatlah dominan. 
Kemiringan Atap

Kemiringan atap masih sangat berhubungan erat dengan bentuk atap, untuk mendukung perwujudan citra suatu fasade bangunan. Hanya saya, kemiringan atap memiliki pilihan yang sangat beragam tidak seperti bentuk atap yang mcmiliki empat pilihan, yaitu datar, pelana, perisai, dan kombinasi - sehingga perbedaan $10^{\circ}$ dianggap sebagai perbedaan yang tidak signifikan.

Warna Atap

Seperti dinyatakan oleh Krier (1988), komposisi dari fasade bangunan disamping berkenaan dengan persyaratan-persyaratan fungsional (jendela, pintu masuk, blinds, dan atap)- pada intinya dilakukan dengan menciptakan kesatuan yang harmonis, dengan menggunakan proporsi yang baik, vertikal dan horizontal yang terstruktur; baik material, warna dan elemen-elemen dekoratif. Sehingga warna dan bahan atap juga merupakan determinan yang diperhitungkan, meskipun tidak setinggi bobot warna dan bahan pada dinding yang memang kedekatannya dengan pengguna jalan (pedestrian) sangatlah tinggi.

Bahan Atap

Seperti yang telah disebutkan sebelumnya, bahwa bahan akan bersifat sama dengan tekstur pada konteks fasade. Hanya saja, karena sudut pandangan pedestrian terhadap atap terlalu tinggi, maka bobot penilaian bahan atap-atap bangunan tergolong rendah - meskipun masih cukup dianggap sebagai salah satu faktor determinan fasade bangunan.

\section{Dinding Bangunan}

Elemen fasade yang terdekat dengan pengguna bangunan adalah dinding bangunan. Bagian terluas dari suatu fasade adalah dinding bangunan. Jadi dinding merupakan faktor penentu utama penilaian terhadap eksistensi bangunan. Kriteria dan komponen penilaian pada dinding bangunan adalah

Proporsi Masif-Transparan pada Dinding

Komponen ini memberikan penilaian efek visual yang ditampilkan oleh perbandingan pembukaan (transparan) dan dinding tertutup (masif). Hal tersebut terlihat dari perbandinganperbandingan bukaan berupa jendela atau pintu tembus pandang (kaca) terhadap bidang dinding yang masif.

Efek Vertikalitas - Horisontalitas pada Dinding

Komponen ini memberikan penilaian mengenai efek visual yang dihasilkan oleh konfigurasi unsur-unsur vertikal dan horizontal dari bidang fasade, misalnya: pola perpetakan jendela/pintu, proporsi jendela/pintu, atau konstruksi sunblinds.

Warna Dinding

Pada Dinding, warna akan sangat berprngaruh terhadap tampilan fasade, karena memiliki porsi view paling besar diantara elemen-elemen fasade yang lainnya. Oleh sebab itu kecenderungan warna dinding pada suatu koridor juga disebut salah satu penentu penataan fasade bangunan.

Bahan Dinding

Yang penting untuk digaris bawahi peran bahan dinding dalam konteks fasade bangunan adalah bahan finishing pada dinding sama dengan tekstur, pemilihan bahan finishing pada dinding juga dapat menimhulkan kesan yang sangat berbeda-beda bagi pengamat. Tekstur kasar yang terkesan menjauhi, tekstur halus yang terkesan menjauhi, serta berbagai macam sifat tekstur lainnya.

\section{Pemunduran Bangunan}

Ada dua variabel yang berkaitan dengan pemunduran bangunan, yaitu Garis Sempadan Banguan (GSB) dan Sky Exposure Plan (SEP). GSB mengatur pemunduran bangunan terhadap ja1an, sedangkan SEP mengatur pemunduran bangunan yang berada di atas podium. Rumusan untuk menentukan tinggi

Hal 125. Langkau Betang, Vol.2, No.2, 2015 
podium bangunan dan pemunduran bangunan di atas podium tersebut, yang dinyatakan dengan perbandingan $\mathrm{H}$ (tinggi puncak bangunan) dan D (jarak antara proyeksi puncak bangunan pada lantai dasar dengan as jalan yang berdampingan). Komponen ini sangat menentukan ruang-ruang hidup yang dapat dipergunakan oleh pemakai bangunan, terutama pada ruang-ruang sisa di area yang paling dekat dengan pedestrian, sehingga cukup berpengaruh pula dalam proses studi fasade bangunan.

\section{Pembahasan dan Hasil}

Membaca dan mengidentifikasi karakteristik dari preseden manakah yang manjadi tema dalam sebuah desain adalah dengan membandingkan langsung fasade, bentuk, pola geometri, skala, bidang vertikal dan horizontal yang mempengaruhi pola desain dari arsitek bersangkutan. Setelah membahas beberapa karakteristik preseden arsitektur dunia pada sub bahasan sebelumnya, maka pada bab ini bahasan itu lebih kepada membandingkan arsitektur beberapa bangunan yang terhitung baru di Kota Makassar, sesuai 4 domain dalam arsitektur yaitu filosofi, engineering, sains, dan arts.

Bahasan mengenai kemiripan raut dari sebuah bentuk geometri bangunan, tidak cuma berarti bahwa bentuk itu terlihat kurang lebih sama, namun kadang-kadang kemiripan dapat dikenali jika semua bentuk tergolong dalam rumpun yang sama. Pertaliannya tidak berdasarkan penglihatan, tetapi berdasarkan psikologi, pola geometri dan karakteristik bentuk yang jelas berulang terlihat dalam sebuah telaah arsitektural khususnya preseden arsitektural. Kemiripan ini dapat terjadi sebagai berikut :

1. Persekutuan: berbagai bentuk akan bersekutu jika dapat dikelompokkan menurut jenis atau makna

2. Peleburan/pengikisan: sebuah bentuk dapat dihasilkan oleh peleburan dua bentuk yang lebih kecil atau pengikisan bentuk yang besar oleh yang kecil.

Berikut adalah beberapa bangunan baru di Makassar yang menjadi objek tinjauan :

\section{Gedung Phinisi Universitas Negeri Makassar}
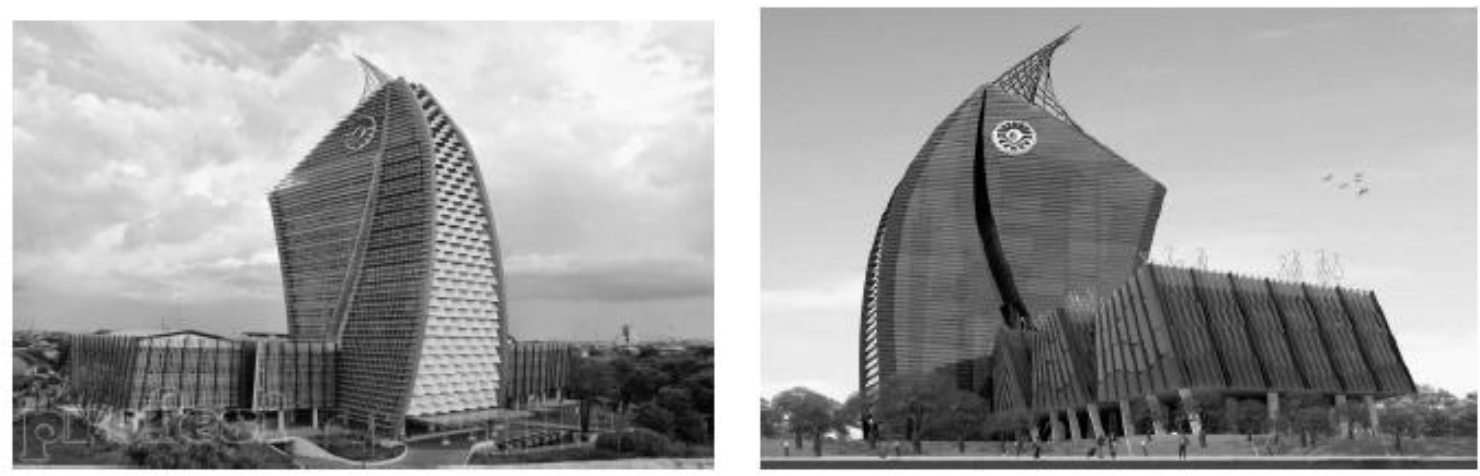

Gambar 26 dan Gambar 27

Organic Curves and Geometric Shape Superimpose

UNM Phinisi Bulding, Makassar - Arsitek Yu sing

Sumber : akanoma architec.com

Gedung Phinisi Universitas Negeri Makassar di bangun pada tahun 2009 secara bertahap, desain bangunan ini di rancang oleh arsitek nasional dari Bandung bernama Yu Sing, yang merupakan pemenang sayembara desain gedung ini.

a. Filosofi

Dilihat dari filosofi, bentuk bangunan ini dipengaruhi oleh filosofi lokalitas kedaerahan Makassar sebagai suku pelaut ulung yang terkenal dengan kapal phinisinya, bentuk tower yang 
menjulang 17 lantai ini didesain berbentuk layar phinisi, adapun bagian podium yang merupakan bangunan berlantai 4 ini didesain dengan filosofi rumah panggung dengan lantai dasar yang kosong sesuai bentuk rumah panggung bugis makassar.

b. Sains

Bentuk seperti ini memerlukan biaya pemeliharaan yang cukup besar, dikarenakan banyaknya folded material dan sirip-sirip fasade yang merupakan material alucarbon, memenuhi sisi bangunan. Disatu sisi merupakan barrier yang baik untuk suara, debu dan angin, namun disisi lain barrier ini membuat suatu medan yang menolak semua radiasi sinar radioaktif sebagaimana karakteristik karbon, otomatis semua perangkat komunikasi mobile terganggu sinyalnya, dan juga merupakan penangkap debu yang lumayan kuat sehingga permukaan sirip-sirip bangunan ini mudah sekali kotor bahkan jika diterpa hujan bisa ditumbuhi lumut dan sekalipun susah untuk tersapu air karna banyaknya folded material pada bangunan ini. Sirip-sirip bangunan ini sepintas dipengaruhi oleh preseden dekonstruksi zaha hadid dengan garis-garis lengkung yang mengalir bebas dan terarah.

c. Engineering

Sepintas bentuk ini adalah permainan struktur, namun sebenarnya hanya permainan kulit bangunan, struktur yang digunakan pun cukup umum yaitu struktur core dan sheer wall yang umumnya digunakan pada bangunan berlantai banyak, hanya saja di aksentuasi dengan permainan luas lantai dan posisi plat lantai yang di atur sedemikian rupa, dengan reduksi dan disorientasi vertical, sesuai konsep superimposition dari Frank Lloyd Wright, Beberapa penampakan struktur podium, sedikit dipengaruhi dengan langgam dekonstruksi Tom Mayne dengan pilar-pilar miring dan tipis.

d. Arts

Sisi Art yang mempengaruhi estetika kuat sekali nampak pada bangunan ini, bentuk dan langgam dekonstruksi yang tersamar menjadikan bangunan ini sebagai point of interest dengan lingkungan sekelilingnya, namun terkait filosofi sebagai bangunan pendidikan, sebaiknya bentuk dan pola desain bukan seperti ini karena sedikit agak bertentangan dengan filosofi pendidikan yang mengangkat nilai-nilai kebenaran (lurus, tegas, jelas) nilai-nilai kejujuran dan open minded (polos,terbuka, menerima). Serta operasional budget dan maintenance yang murah serta mudah dalam aplikasinya.

\section{Gedung Trans Studio Mall Makassar}
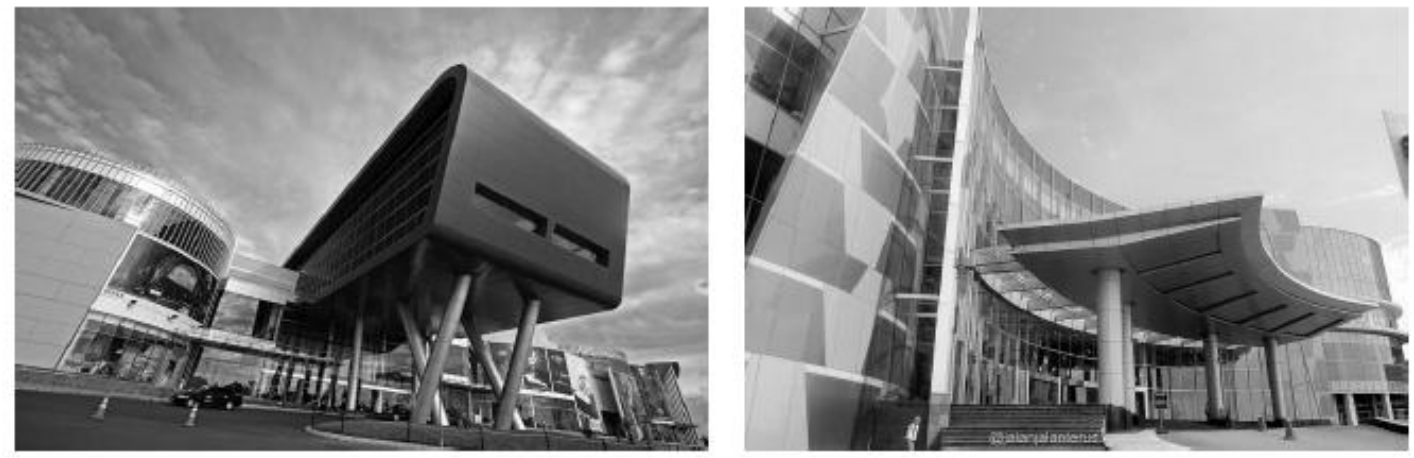

Gambar 28 dan Gambar 29

Superimpose, hybrid dan Kantilever Dekonctruksi

Trans Studio Mall, Makassar - Arsitek DP Singapore \& Arkonin

Sumber : foto lapangan

Hal 127. Langkau Betang, Vol.2, No.2, 2015 
Gedung ini adalah sebuah mall yang dibangun di area Tanjung Bunga, pada tahun 2010, merupakan proyek dari Trans corp. yang berinvestasi di Makassar dalam bidang komersial building. Dengan luas kawasan hampir $10 \mathrm{Ha}$, kawasan komersial ini mempunyai berbagai program dan fungsi yang multiply dalam kawasannya, yaitu Mall, Bank, Civic Center dan Taman Hiburan Masyarakat.

a. Filosofi

Secara filosofi desain bangunan ini lebih kental dengan gaya bebas dan dinamis ekspresif, pola geometri dan bentuk yang bebas mencirikan bagaimana bangunan ini menjadi magnet dalam kawasannya, sesuai fungsi komersialitasnya. Namun secara samar filosofi lokal kedaerahan masih bisa terlihat di entrance masuk, sebagai pengaruh filosofi rumah panggung. Namun secara kental, langgam dekonstruksi sangat berpengaruh pada desain bangunan ini.

b. Sains

Dilihat dari domain sains, bentuk dan pola bangunan ini menerapkan pola lempeng geometri secara bebas, aktif, dinamis dan tidak berorientasi terpusat, objek-objek geometri yang berbeda ukuran, orientasi, warna dan bentuknya ini memenuhi fasade bangunan di sesuaikan dengan program fungsi ruang masing-masing, bukaan yang massiv dan warna yang dinamis dan pola mozaik yang kental, garis-garis vertical dan horizontal yang berorientasi bebas dan tidak terarah, menjelaskan betapa langgam hybrid Coop Himmelblau dan dekonstruksi Tom Mayne menguasai dangan sempurna.

c. Engineering

Dari segi domain engineering, dengan konsep hybrid dan dekonstruksi yang kental, membuat issu struktur advance menjadi issu yang harus di utamakan pada bangunan ini, menyangkut kekuatan, ketahanan, life span, dan maintenance. Dengan kulit material alucarbon yang tersusun polos tanpa folded material, membuat bangunan ini menjadi mudah dalam pemeliharaan dan murah dalam pembiayaan life cycle cost.

d. Arts

Seni Kontemporer abstrak menjadi wajah bangunan ini, dinamisme dan irama pola dan bentuk bangunan, membuat bangunan ini menjadi kolase yang baik dalam memperkaya panorama perkotaan di Makassar khususnya.

\section{Gedung Kalla Tower Makassar}
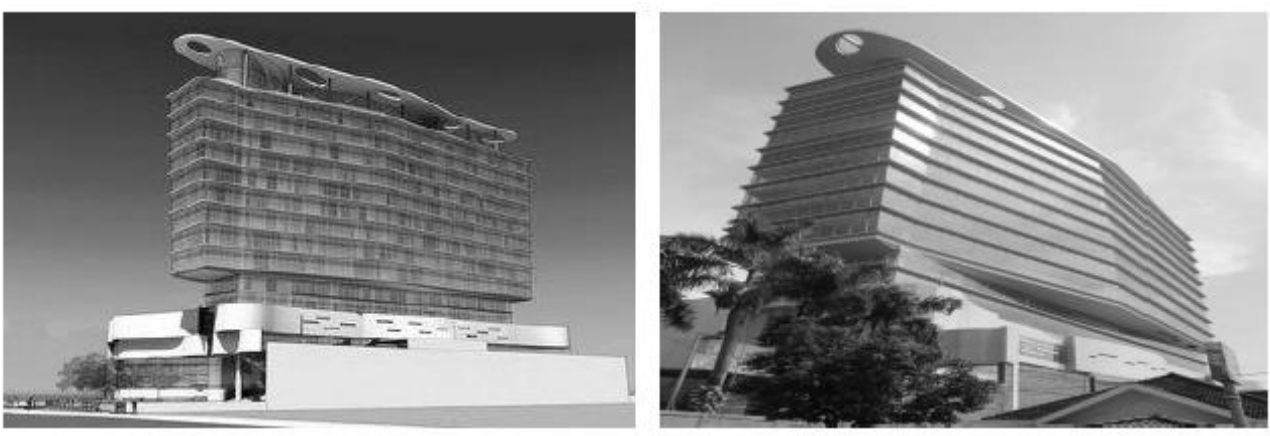

Gambar 30 dan Gambar 31

Superimpose dan Hybrid Geometri

Wisma Kalla Tower, Makassar - Arsitek Baskoro Tedjo.

Sumber : foto lapangan 
Gedung berlantai 15 ini adalah sebuah rental office milik group kalla, sebuah korporasi konglomerat yang mempunyai banyak anak perusahaan yang bergerak di segala bidang. Gedung ini didirikan pada tahun 2009, diatas tanah 5.500 meter persegi, terdiri dari tower 15 lantai dan podium 5 lantai dan diberi nama Wisma Kalla.

a. Filosofi

Filosofi bangunan ini murni berlanggam international style, garis-garis vertikal yang tegas dan bukaan yang masif dengan bidang jendela kaca yang full memenuhi sisi bangunan. Tidak terlihat adanya ciri khas kelokalan dan kedaerahan. Pengaruh modernitas dan hybrid yang sangat kental.

b. Sains

Domain sains yang berlaku pada bangunan ini, adalah bagaimana maintenance dan pengaruhnya terhadap lingkungan, mengingat bangunan ini adalah bangunan kaca maka perlu perlakuan khusus terhadap pengkondisian thermal dan pengkondisian udara, secara otomatis manjauhkan bangunan ini ke klaim green building karena biaya maintenance yg tidak murah serta pengaruh pantulan pencahaayaan ke lingkungan yang berimplikasi dengan radiasi cahaya dan panas yang meningkat utk lingkungan sekitar.

c. Engineering

Struktur bangunan ini masih umum apa yang di aplikasikan untuk bangunan berlantai banyak, yaitu struktur core dan sheerwall, pengaturan layout lantai yang membentuk tower tersusun berarah dengan orientasi tetap. Pada podium bangunan pun terlihat dengan pengaturan layout yang fleksibel dengan garis lengkung dinamis yang mengalir bebas, dekonstruksi preseden zaha hadid cukup berpengaruh pada bangunan ini.

d. Arts

Melihat bentuk dan pola objek geometri bangunan ini, dapat dikategorikan sebagai seni konservatif, model rigid dan layout yang jelas, membuat penampakannya polos dan jujur. Adapun beberapa lempeng geometri yang mengadaptasi lengkungan dan garis garis yag mengalir fleksibel, hanya sebagai ornament tambahan dan bukan sebagai struktur. Melihat garis besarnya bangunan ini dipengaruhi oleh preseden Richard meyer.

\section{Gedung Makassar Trade Centre dan Condotel}
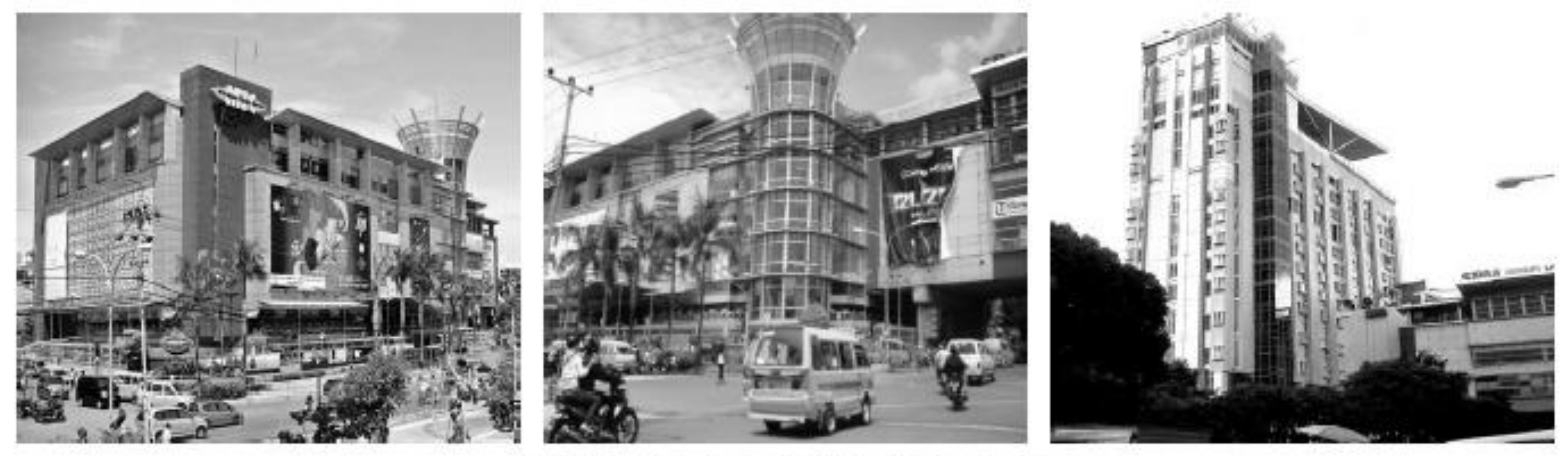

Gambar 32 - Gambar 33 - Gambar 34

Superimposisi Bentuk Geometri dan Ruang

Makassar Trade Center Mall, Makassar - Desain Inc.Australia.

Sumber : foto lapangan

Gedung berlantai 6 ini adalah sebuah Mall dengan sistem investasi dari PT.Tosan Permai Lestari yang share dengan pemerintah kota Makassar, didirikan tahun 2001 secara bertahap, pembangunan diperluas sehingga memiliki junction yang mengangkangi jalan khairil anwar serta memiliki

Hal 129. Langkau Betang, Vol.2, No.2, 2015 
condominium hotel berlantai 12 yang didirikan thn 2012, dengan konsep multi fungsi sekaligus mix use building, bangunan ini menjadi salah satu ikon di kota Makassar.

a. Filosofi

Secara filosofi desain bangunan ini lebih kental dengan gaya dinamis ekspresif, pola geometri dan bentuk yang bebas serta beraneka ragam juga penggunaan warna yang kuat mencirikan bagaimana bangunan ini menjadi magnet dalam kawasan, sesuai fungsi komersial nya. Secara kental, langgam dekonstruksi sangat berpengaruh pada desain bangunan ini khususnya aliran preseden Richard Meyer serta Dominique Perrault.

b. Sains

Dilihat dari domain sains, bentuk dan pola bangunan ini menerapkan pola lempeng geometri secara bebas, aktif, dinamis dan tidak berorientasi terpusat, objek-objek geometri yang berbeda ukuran, orientasi, warna dan bentuknya ini memenuhi fasade bangunan di sesuaikan dengan program fungsi ruang masing-masing, bukaan yang massiv dan warna yang dinamis dan pola mozaik yang kental, garis-garis vertical dan horizontal yang berorientasi bebas dan tidak terarah, menjelaskan betapa langgam dekonstruksi Richard Meyer dan Dominique Perrault, menguasai dangan sempurna.

c. Engineering

Dari segi domain engineering, dengan konsep Transposisi dan dekonstruksi yang kental, membuat issu struktur advance menjadi issu yang harus di utamakan pada bangunan ini, menyangkut kekuatan, ketahanan, life span, dan maintenance. Dengan kulit material alucarbon yang tersusun dinamis dengan sedikit aksen folded material, serta bended material membuat bangunan ini menjadi sedikit rumit dalam pemeliharaan dan relative mahal dalam pembiayaan life cycle cost.

d. Arts

Seni Kontemporer abstrak menjadi wajah bangunan ini, dinamisme dan irama pola dan bentuk bangunan, membuat bangunan ini menjadi kolase yang baik dalam memperkaya panorama perkotaan di Makassar khususnya.

\section{Gedung Graha Pena Makassar}
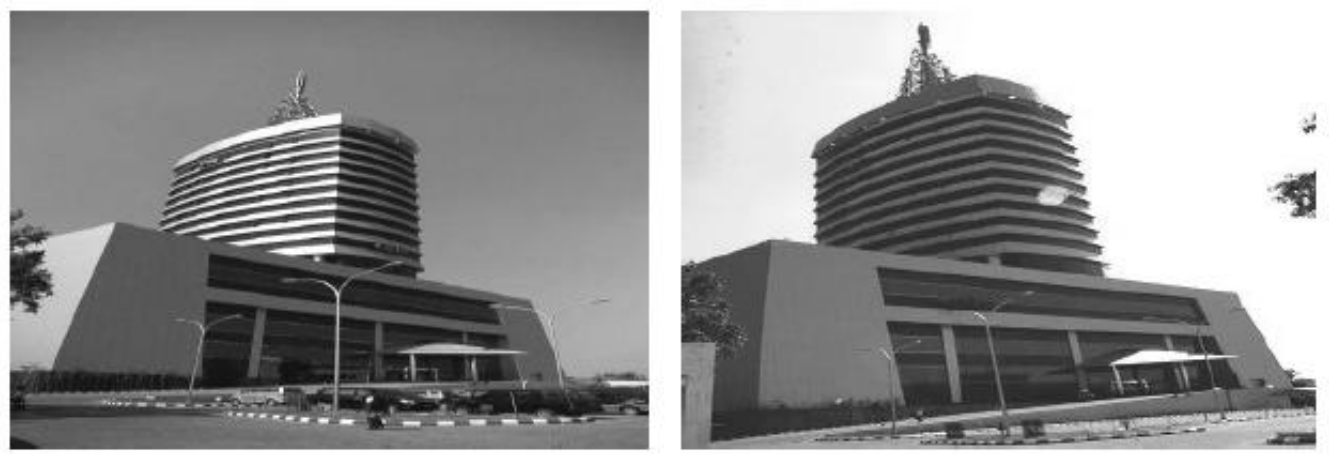

Gambar 35 dan Gambar 36 Superimposisi Bentuk Geometri

Gedung Graha Pena, Makassar - Fajar Group.

Sumber : foto lapangan 
Gedung berlantai 17 ini adalah sebuah Rental Office milik Fajar group, sebuah korporasi yang mempunyai banyak anak perusahaan yang bergerak di bidang Media Pemberitaan dan broadcasting. Gedung ini didirikan pada tahun 2007, terdiri dari tower 17 lantai dan podium 5 lantai.

a. Filosofi

Filosofi bangunan ini murni berlanggam international style, garis-garis vertikal yang tegas dan bukaan yang masif dengan bidang jendela kaca yang full memenuhi sisi bangunan. Tidak terlihat adanya ciri khas kelokalan dan kedaerahan. Pengaruh modernitas dan hybrid yang sangat kental.

b. Sains

Domain sains yang berlaku pada bangunan ini, adalah bagaimana maintenance dan pengaruhnya terhadap lingkungan, mengingat bangunan ini adalah bangunan kaca maka perlu perlakuan khusus terhadap pengkondisian thermal dan pengkondisian udara, secara otomatis manjauhkan bangunan ini ke klaim green building karena biaya maintenance yg tidak murah serta pengaruh pantulan pencahaayaan ke lingkungan yang berimplikasi dengan radiasi cahaya dan panas yag meningkat utk lingkungan sekitar.

c. Engineering

Struktur bangunan ini masih umum apa yang di aplikasikan untuk bangunan berlantai banyak, yaitu struktur core dan sheerwall, pengaturan layout lantai yang membentuk tower tersusun berarah dengan orientasi tetap. Pada podium bangunan pun terlihat dengan pengaturan layout yang jelas dengan garis vertikal dan horizontal yang tegas, langgam superimpisition preseden Frank Lloyd Wright cukup berpengaruh pada bangunan ini.

d. Arts

Melihat bentuk dan pola objek geometri bangunan ini, dapat dikategorikan sebagai seni konservatif, model rigid dan layout yang jelas, membuat penampakannya polos dan jujur. Adapun beberapa pola geometri yang berulang dan garis-garis yang tegas, hanya sebagai ornament tambahan dan bukan sebagai struktur. Melihat garis besarnya bangunan ini dipengaruhi oleh preseden Frank Lloyd Wright.

\section{Gedung Private Care Centre R.S Wahidin}


Hal 131. Langkau Betang, Vol.2, No.2, 2015 
Gedung berlantai 10 ini adalah sebuah Rumah Sakit Umum Regional, Fungsi bangunan ini diperuntukkan untuk pasien pasien yang mengalami gangguan kesehatan yang akut dan membutuhkan private acces dan private maintenance yang intensif. Gedung ini didirikan pada tahun 2010.

a. Filosofi

Filosofi bangunan ini murni berlanggam international style, garis-garis vertikal yang tegas dan bukaan yang massive dengan bidang jendela kaca yang penuh memenuhi sisi bangunan.Tidak terlihat adanya ciri khas kelokalan dan kedaerahan. Pengaruh modernitas dan hybrid yang sangat kental.

b. Sains

Domain sains yang berlaku pada bangunan ini, adalah bagaimana maintenance dan pengaruhnya terhadap lingkungan, mengingat bangunan ini adalah bangunan kaca maka perlu perlakuan khusus terhadap pengkondisian thermal dan pengkondisian udara, secara otomatis manjauhkan bangunan ini ke klaim green building karena biaya maintenance yang tidak murah serta pengaruh pantulan pencahaayaan ke lingkungan yang berimplikasi dengan radiasi cahaya dan panas yag meningkat utk lingkungan sekitar.

c. Engineering

Struktur bangunan ini masih umum apa yang di aplikasikan untuk bangunan berlantai banyak, yaitu struktur core dan sheerwall, pengaturan layout lantai yang membentuk tower tersusun berarah dengan orientasi tetap. Pada podium bangunan pun terlihat dengan pengaturan layout yang jelas dengan garis vertikal dan horizontal yang tegas, langgam superimposition preseden Frank Lloyd Wright cukup berpengaruh pada bangunan ini.

d. Arts

Melihat bentuk dan pola objek geometri bangunan ini, dapat dikategorikan sebagai seni konservatif, model rigid dan layout yang jelas, membuat penampakannya polos dan jujur. Adapun beberapa pola geometri yang berulang dan garis-garis yang tegas, sebagai ornament tambahan dan bukan sebagai struktur. Melihat garis besarnya bangunan ini dipengaruhi oleh preseden Frank Lloyd Wright.

\section{Sultan Hasanuddin International Airport}

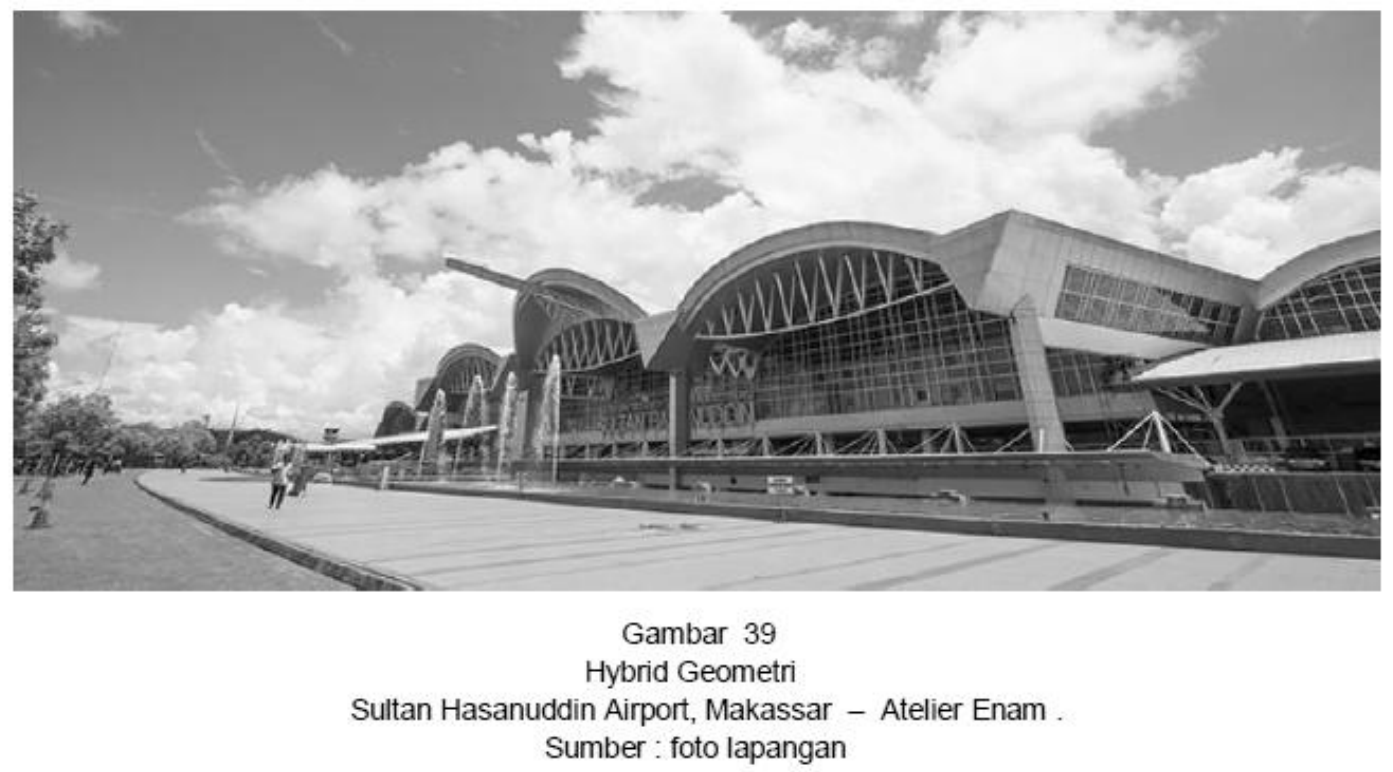

Langkau Betang, Vol.2, No.2, 2015. Hal. 132 
Gedung berlantai 4 dengan bentang lebar ini adalah sebuah International Airport yang terletak di kabupaten Maros. Gedung ini didirikan pada tahun 2005

a. Filosofi

Filosofi bangunan ini murni berlanggam international style, garis-garis vertikal yang tegas dan bukaan yang massive dengan bidang jendela kaca yang penuh memenuhi sisi bangunan.Tidak terlihat adanya ciri khas kelokalan dan kedaerahan. Pengaruh modernitas dan hybrid yang sangat kental.

b. Sains

Domain sains yang berlaku pada bangunan ini, adalah bagaimana maintenance dan pengaruhnya terhadap lingkungan, mengingat bangunan ini adalah bangunan kaca maka perlu perlakuan khusus terhadap pengkondisian thermal dan pengkondisian udara, selain itu bentuknya mengakomodasi aliran angin yang dihasilkan dari pusaran udara oleh turbin pesawat.

c. Engineering

Struktur bangunan bentang lebar atau long wide span, pada umumnya memakai konstruksi baja atau komposit, dengan pertimbangan rigiditas dan fleksibilitas terhadap terpaan angin dan turbulensi udara yang dihasilkan oleh turbin pesawat. Struktur baja dan komposit ini kental akan preseden dekonstruksi dari Ricardo legorretta.

d. Arts

Seni Kontemporer abstrak menjadi wajah bangunan ini, dinamisme dan irama pola dan bentuk bangunan, membuat bangunan ini menjadi kolase yang baik dalam memperkaya panorama perkotaan di Makassar khususnya.

\section{Celebes Convention Centre}
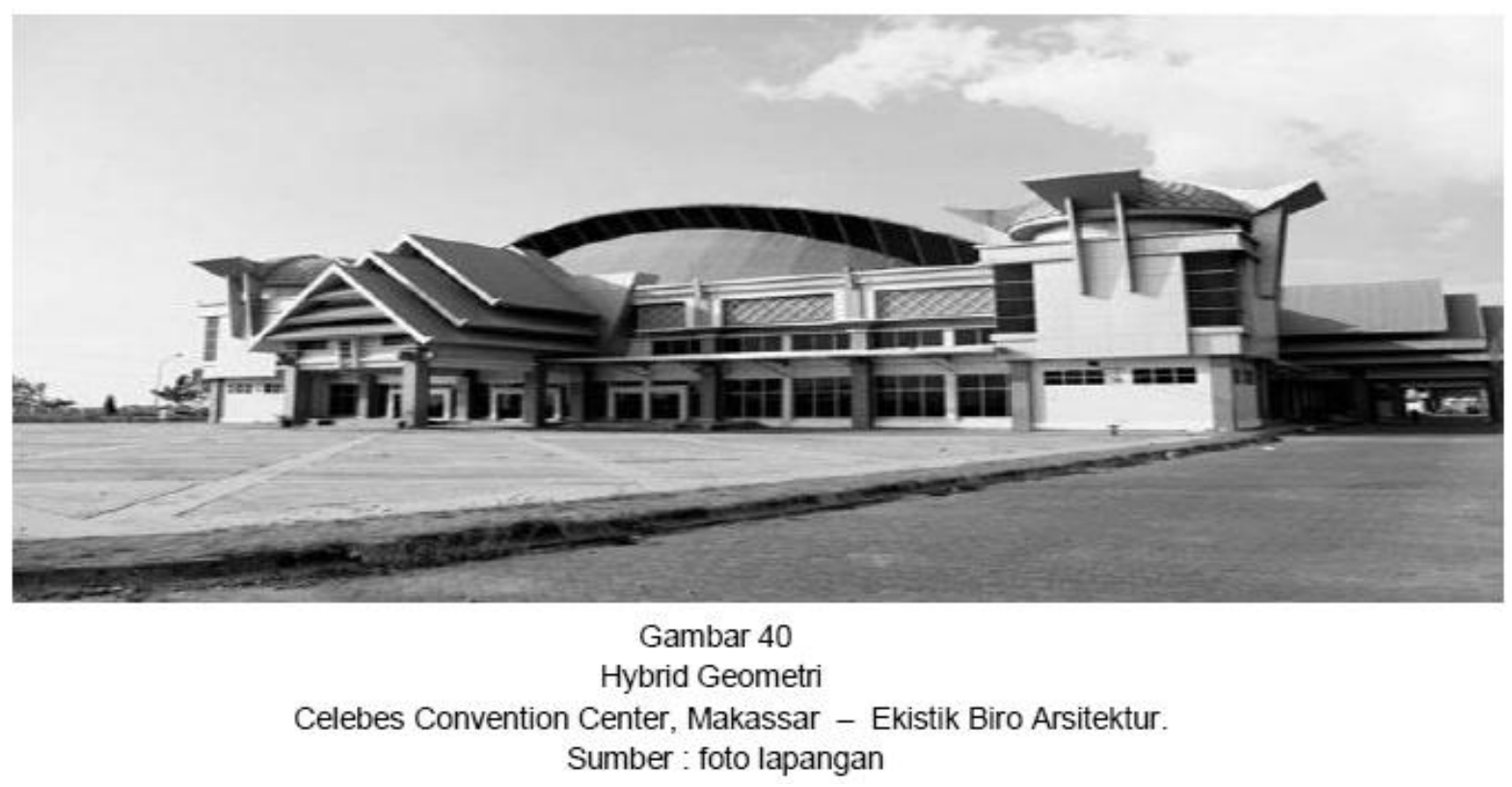

Gedung ini adalah sebuah Convention Center tempat pertemuan atau pameran. Gedung ini didirikan pada tahun 2006, dengan komposisi bangunan lebar dan luas untuk menunjang fungsi keruangan yang menjadi target program perancangannya.

a. Filosofi 
Filosofi bangunan ini berlanggam international style, dan local wisdom, garis-garis horizontal yang tegas dan ornament yang menempel hanya sebagai objek seni. Terlihat adanya ciri khas kelokalan dan kedaerahan. Pengaruh modernitas dan hybrid local wisdom cukup kelihatan.

b. Sains

Domain sains yang berlaku pada bangunan ini, adalah bagaimana maintenance dan pengaruhnya terhadap lingkungan, mengingat bangunan ini adalah bangunan yang penuh dengan folded shape dan folded material, merupakan bantuk penangkap angin yang baik namun juga perangkap untuk debu serta kotoran yang terbawa angin, dengan permukaan dinding konvensional (cat,plamur dan agregat) membuar permukaan kasarnya adalah pengumpul partikel padat mikroskopis yang walaupun tersapu air hujan akan berlumut dan cukup sulit untuk dibersihkan kembali.

c. Engineering

Struktur bangunan ini termasuk struktur bentang lebar, terlihat kubah sebagai topping dari bangunan ini menggunakan konstruksi baja. Pada bangunan pun terlihat dengan pengaturan layout yang jelas dengan garis vertikal dan horizontal yang tegas, langgam superimpisition preseden Richard Meyer cukup berpengaruh pada bangunan ini.

d. Arts

Melihat bentuk dan pola objek geometri bangunan ini, dapat dikategorikan sebagai seni konservatif, model rigid dan layout yang jelas. Dengan beberapa lempeng geometri yang berulang dan garis- garis yang tegas, hanya sebagai ornament tambahan dan bukan sebagai struktur.

\section{Mall Ratu Indah Makassar}
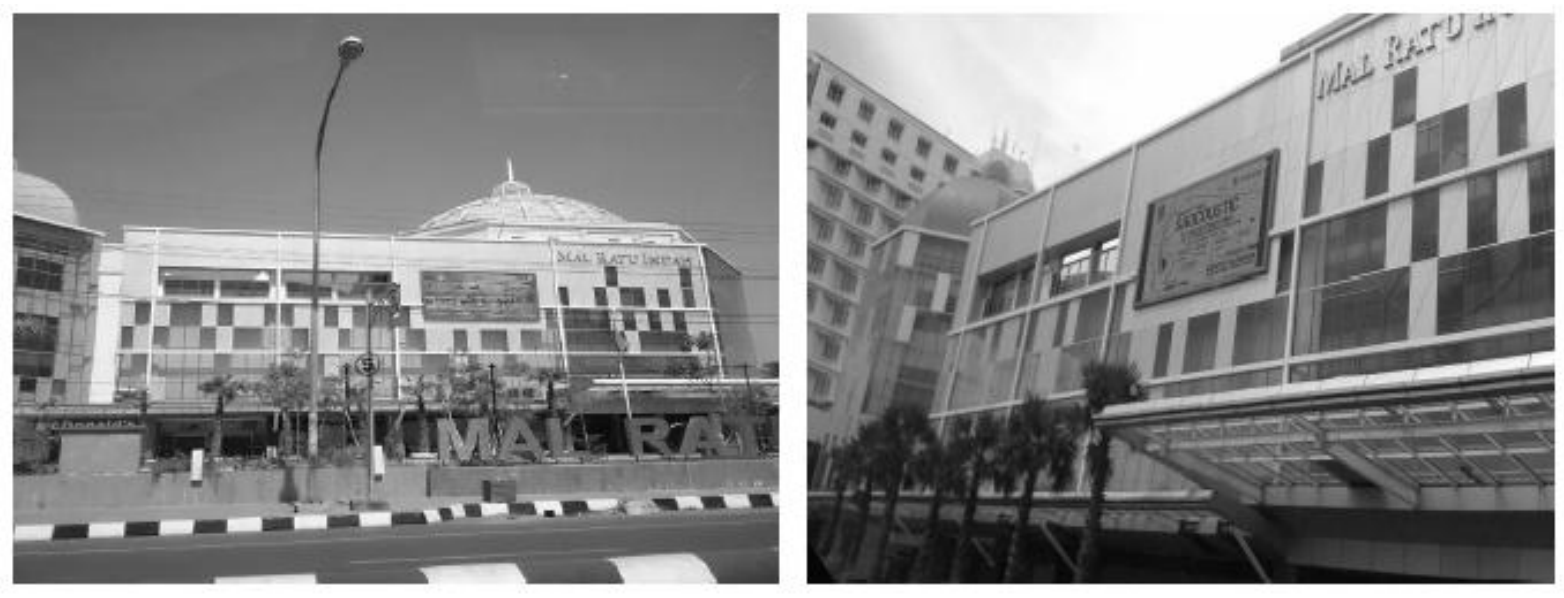

Gambar 41 dan Gambar 42

Superimpose Geometri

Mall Ratu Indah, Makassar - Kalla Group.

Sumber : foto lapangan

Gedung berlantai 4 ini adalah sebuah Mall milik Kalla group, sebuah korporasi yang mempunyai banyak anak perusahaan yang bergerak di banyak bidang. Gedung ini didirikan pada tahun 1999.

a. Filosofi

Filosofi bangunan ini murni berlanggam international style, garis-garis vertikal yang tegas dan bukaan yang massive dengan bidang jendela kaca yang penuh memenuhi sisi bangunan.Tidak 
terlihat adanya ciri khas kelokalan dan kedaerahan. Pengaruh modernitas dan superimpose yang sangat kental.

b. Sains

Domain sains yang berlaku pada bangunan ini, adalah bagaimana maintenance dan pengaruhnya terhadap lingkungan, mengingat bangunan ini adalah bangunan kaca maka perlu perlakuan khusus terhadap pengkondisian thermal dan pengkondisian udara, secara otomatis manjauhkan bangunan ini ke klaim green building karena biaya maintenance yg tidak murah serta pengaruh pantulan pencahaayaan ke lingkungan yang berimplikasi dengan radiasi cahaya dan panas yag meningkat utk lingkungan sekitar.

c. Engineering

Struktur bangunan ini masih umum apa yang di aplikasikan untuk bangunan berlantai banyak, yaitu struktur core dan sheerwall, pengaturan layout lantai yang membentuk tower tersusun berarah dengan orientasi tetap. Pada podium bangunan pun terlihat dengan pengaturan layout yang jelas dengan garis vertikal dan horizontal yang tegas, langgam superimpisition preseden Frank Lloyd Wright cukup berpengaruh pada bangunan ini.

d. Arts

Melihat bentuk dan pola objek geometri bangunan ini, dapat dikategorikan sebagai seni konservatif, model rigid dan layout yang jelas, membuat penampakannya polos dan jujur. Adapun beberapa lempeng geometri yang berulang dan garis garis yang tegas, hanya sebagai ornament tambahan dan bukan sebagai struktur. Melihat garis besarnya bangunan ini dipengaruhi oleh preseden Frank Lloyd Wright.

\section{Kesimpulan}

1. Fasade bangunan komersial umumnya telah terpengaruh secara massive, dengan presedenpreseden arsitektur luar, tampak dari pola-pola geometri dan bentuk serta ornamen intinya.

2. Fasade bangunan pemerintahan atau bangunan non komersial pada umumnya pola dan bentuknya masih beradaptasi dengan lingkungan dan iklim tropis di Indonesia khususnya di Kota Makassar, namun pengaruh-pengaruh preseden itu tetap ada walau sebatas ornament kulit luar.

3. Karakteristik langgam art-deco arsitektur eropa beradaptasi menjadi langgam neo vernakular arsitektur tropis Indonesia untuk bangunan non komersial.

4. Karakteristik langgam international style dan dekontruksi lebih menguasai langgam bangunan komersial.

5. Bahwa Arsitek yang berperan dalam desain bangunan-bangunan yang telah terpengaruh preseden arsitektur luar semacam dekonstruksi, hybrid, superimpose, Morphosis, International style, adalah arsitek - arsitek dari lulusan tahun 1998 keatas atau bahkan arsitek dari luar, dimana preseden sudah mulai memasuki post modern yaitu langgam International style dan langgam dekonstruksi pd tahun 1995.

\section{Saran}

1. Menjadikan referensi atau pedoman perencanaan tata ruang bangunan konservasi atau bangunan modern pada kawasan berkarakter dan menjadi suatu potensi yang mengangkat nilai ruang perkotaan dengan lokal wisdom atau langgam modern.

2. Sebagai usulan kepada pemerintah kota dan daerah dalam mengembangkan kawasan-kawasan berkarakter dan bangunan-bangunan modern dalam upayanya manjadikan wajah kota yang dinamis serta tertata di lihat dari sisi revitalisasi kawasan lama perkotaan tanpa merusak wajah kota lama sebagai ikon kawasan yang sudah terbentuk.. 
3. Sebagai referensi kepada pihak swasta bagaimana mengatur fasade dalam kawasan yang berkarakter khususnya dalam area konservasi sehingga tidak merusak wajah sebagai ikon kawasan yg sudah terbentuk.

\section{Daftar Pustaka}

Alan Johnson, Paul. (1994). The Theory of Architecture: Concept, Themes \& Practices, New York, Van Nostrand Reinhold

Antoniades, A.C. (1991). Poetic Of Architecture, New York, Van Nostrand Reinhold Atmoko, Adi Utomo (2003), Teori Arsitektur III, Buku Ajar, Yogyakarta, Universitas Gadjah Mada

Ching, Francis D.K. (1993). Architectural Concept,US,American Institut of Architec.

Cooke, Catherine. (1984). Fantasy and Architecture, United Kingdom, Academy Group Ltd.

Frazer, Jhon. (1995). An Evolusionary Architecture, London, Architectural Association

Grand Architecture. (1997). Bernard Tscumi Document Extra vol.10, Tokyo, Japan, A.D.A EDITA Tokyo Co.Ltd

Grand Architecture. (1997). Morphosis Document Extra vol.9, Tokyo, Japan, A.D.A EDITA Tokyo Co.Ltd

Grand Architecture. (1997). Richard Meyer Document Extra vol.8, Tokyo, Japan, A.D.A EDITA Tokyo Co.Ltd

Grand Architecture. (1997). Tadao Ando Document Extra vol.1, Tokyo, Japan, A.D.A EDITA Tokyo Co.Ltd.

H.B. Sutopo. (2002). Metodologi Penelitian Kualitatif. Surakarta : Sebelas Maret University Press.

Heryanto, Bambang. (2003). Sejarah Arsitektur, Makassar, Hasanuddin University Press.

I. Makainas, (2011), Eksplorasi terhadap Arsitektur Dekonstruksi, Jurnal Media Matrasain Vol.8No.2,Manado, Fakultas Teknik Arsitektur Universitas Sam Ratulangi

Jeramain, Philipus. (2010). Teori Arsitektur III, Buku Ajar, Kupang, Universitas Katolik Widya Mandira Lync, Kevin. (1977). Site Planning, American Institute of Architect

Poernomo, S. (1992), Paradoks Arsitektur Dekonstruksi, Jakarta, Majalah Konstruksi Edisi April

Siregar, Fritz O.P. (2011). Penilaian Terhadap Arsitektur, Jurnal Media Matrasain Vol.8-No.1, Manado, Fakultas Teknik Arsitektur Universitas Sam Ratulangi.

Steiner, Frederik. (2007). Planning and Urban design Standarts, American Planning Association.

Sutanto, Agustinus. (2001). Gagasan Koneksi Ruang, Kamasutra, Seminar Nasional Arsitektur, Depok, Universitas Indonesia.

Tjahyono, G. (1998). Indonesian Heritage: Architecture, Singapore Archipelago Press

White, Edward.T. (1973). Ordering System: an introduction to architectural design, Tucson Arizona, University of Arizona.

http//www.Arcspace.com

http//www.Architecture Digest.com

http//www.Enric Miralles.com

http//www.Eric Owen Moss.com

http//www.Frank Gehry.com

http//www.Geocities.com/sta5_ar530/tugas_kelompok/kelompok6/BABV.html

http//www.Morphosis.com

http//www.Tom Mayne.com

http//www.Thomas Meyer Archive.de

http//www.Zaha Hadid Architec.com 